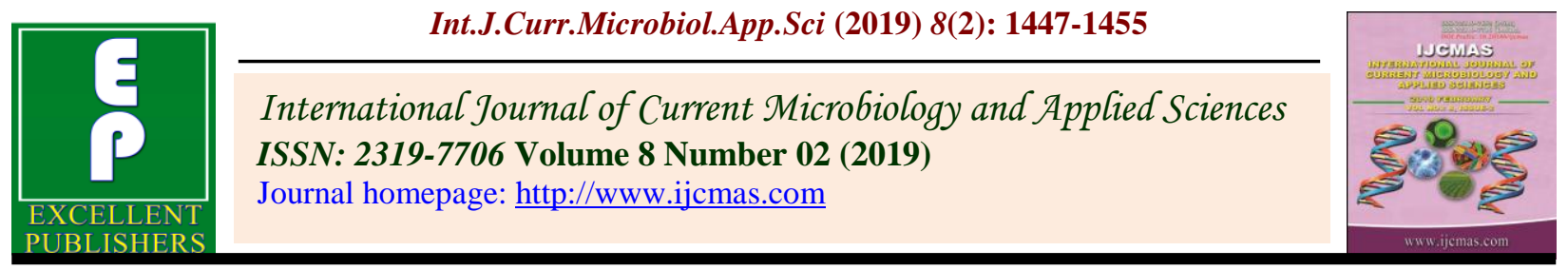

Original Research Article

https://doi.org/10.20546/ijcmas.2019.802.168

\title{
Effect of Foliar Application of Different Sources and Levels of Calcium on Physico-Chemical Properties of Harvested Soil and Correlation of Calcium Nutrition with Fruit Quality
}

\author{
A. Tejashvini* and G.N. Thippeshappa
}

Department of Soil Science, College of Agriculture, Shivamogga-577204, Karnataka, India

*Corresponding author

\section{A B S T R A C T}

\section{Keywords}

Calcium, Tomato,

Nutrient status,

Correlation

Article Info

Accepted:

12 January 2019

Available Online:

10 February 2019
Poly house experiment was carried out at Zonal Agricultural and Horticultural Research Station (ZAHRS), Navile, Shivamogga during kharif2016 to study the response of tomato fruit to different sources and levels of calcium. Three sources of calcium $\left[\mathrm{CaCl}_{2}, \mathrm{CaNO}_{3}\right.$ and calcium ammonium nitrate $(\mathrm{CAN})]$ with three levels each $(0.20,0.50$ and $0.80 \%)$ were applied as a foliar spray in a Complete Randomized Design (CRD) with three replications and ten treatments. The results of experiment indicated that foliar application of calcium through different sources increased the yield of tomato significantly over the control (water spray) due to more uptake and utilization of nutrients from the soil after harvesting of tomato crop. The least nutrient status was recorded $\left(164.34 \mathrm{~kg} \mathrm{ha}^{-1}, 38.49 \mathrm{~kg} \mathrm{ha}^{-1}\right.$, $255.84 \mathrm{~kg} \mathrm{ha}^{-1}, 5.30 \mathrm{meq} 100 \mathrm{~g}^{-1}, 2.57 \mathrm{meq} 100 \mathrm{~g}^{-1}, 3.72 \mathrm{ppm}, 10.32 \mathrm{ppm}, 1.96 \mathrm{ppm}, 6.97 \mathrm{ppm}$ and $1.94 \mathrm{ppm}$, respectively) in treatment receiving 0.5 per cent CAN as foliar spray $\left(\mathrm{T}_{9}\right)$ followed by foliar spray of $0.5 \%$ CAN compared to control, it has recorded highest nutrient status in soil. The correlation study indicates the relationship between calcium nutrition with growth; yield and fruit quality parameters were positively and significantly correlated.

\section{Introduction}

Tomato (Solanum lycopersicum L.), belongs to the family Solanaceae, is one of the most important vegetable crops grown throughout the world because of its wider adaptability and utility. The tomato is considered as "Poor Man's Orange" in India, and "Love of apple" in England. The tomato pulp and juice are very appetizing, easily digestible, promoters of gastric secretion, blood purifiers and have a pleasing and refreshing taste.
Calcium $(\mathrm{Ca})$ is an element that differs from others by being imported into fleshy fruit only in small amounts, much less than into leaves. Foliar applied fertilizers usually compensate for or alleviate this inadequacy (Erdal et al., 8; Lanauskas and Kvikliene, 10). Foliar nutrition plays an important role in increasing nutrient content in fruiting vegetables using calcium fertilizers. Sprays of $\mathrm{Ca}$ normally prevent most physiological disorders, but the degree of success varies according to natural predisposition to the symptoms, growing season, cultivar, and environmental 
conditions. There are evidences to suggest that the increase of calcium in the fruits resulting from $\mathrm{Ca}$ sprays, however, is normally low or even inexistent. Moreover, calcium fertilizers have a consistent effect on fruit flesh firmness, soluble solids content and natural weight loss.

It is essential for the formation of cell wall and calcium pectate in the middle lamella of the cell wall which regulates the entry of only those nutrients which are nontoxic to plants. In seeds, calcium is present as calcium pectate. In root tip, calcium is very essential for the meristematic activity, provides a base for neutralisation of organic acids and other toxins (like Aluminum) produced in plants. It plays a role in mitosis (cell division) and helps to maintain the chromosome structure. It is essential co-factor or an activator of a number of enzymes like hydrolases. It activates phospholipase, arginine kinase, amylase and adenosine tri phosphatase (ATPase) enzymes. It favours the assimilation of nitrogen into organic constituents especially proteins.

In spite of its pivotal role in crop nutrition, but less importance and work has been done in crop production especially in vegetable crops as it is a secondary nutrient and most neglected element. Moreover, Hence, an experiment was planned to know the efficiency of different sources and levels of $\mathrm{Ca}$ through foliar spray on tomato crop and soil physic-chemical properties.

\section{Materials and Methods}

A polyhouse experiment was conducted at ZAHRS, Navile, Shivamogga, in Karnataka state in India, during 2016-17. The experimental site is situated at $14^{0} 0$ ' to $14^{0} 1^{\prime}$, North latitude and $75^{\circ} 40^{\prime}$ to $75^{\circ} 42^{\prime}$ east longitude with an altitude of 650 meters above the mean sea level. The experiment comprised 10 treatment combinations with three calcium sources and three levels tried under naturally ventilated poly house condition with tomato hybrid 'ArkaSamrat' which was released from Indian Institute of Horticultural Research, Bangalore, India as test crop. The experiment was laid out in Completely Randomized Design (CRD) with three replications. The recommended doses of fertilizers were applied @ 250: 250: $250 \mathrm{~N}$, $\mathrm{P}_{2} \mathrm{O}_{5}$, and $\mathrm{K}_{2} \mathrm{O} \mathrm{kg} \mathrm{ha}{ }^{-1}$ to all the treatments through Urea, Diammonium phosphate (DAP, Murate of potash (MOP).

The different sources of calcium fertilizer were used as a foliar nutrition viz., calcium chloride $\left(\mathrm{CaCl}_{2}\right)$, calcium nitrate $\left(\mathrm{CaNO}_{3}\right)$ and calcium ammonium nitrate $(\mathrm{CAN})$ at 0.20 , 0.50 and 0.80 per cent concentration each. Seedlings were produced in pro-trays containing coco-peat as potting mixture. After 20 days of sowing, healthy plants were transplanted to main raised beds under polyhouse.

The soil samples were collected from the different treatments after harvest of the crop to know the nutrient status of soil. Collected samples were processed and analyzed for nutrient status by following standard methods of analysis (Jackson, 1973; Page et al., 1982; Subbaiah and Asija, 1956; Black, 1965; Lindsay and Norvell, 1978). And correlation is studied to know the relationship between the calcium nutrition on fruit quality (Gomez and Gomez, 1984).

\section{Treatment details}

$\mathrm{T}_{1}$ : Water spray (Control)

$\mathrm{T}_{2}$ : Calcium chloride $\left(\mathrm{CaCl}_{2}\right)$ @ $0.2 \%$ Foliar Spray

$\mathrm{T}_{3}$ : Calcium chloride $\left(\mathrm{CaCl}_{2}\right) @ 0.5 \%$ Foliar Spray

$\mathrm{T}_{4}$ : Calcium chloride $\left(\mathrm{CaCl}_{2}\right)$ @ $0.8 \%$ Foliar Spray 
$\mathrm{T}_{5}$ : Calcium nitrate $\left(\mathrm{CaNO}_{3}\right) @ 0.2 \%$ Foliar Spray

$\mathrm{T}_{6}$ : Calcium nitrate $\left(\mathrm{CaNO}_{3}\right) @ 0.5 \%$ Foliar Spray

$\mathrm{T}_{7}$ : Calcium nitrate $\left(\mathrm{CaNO}_{3}\right) @ 0.8 \%$ Foliar Spray

$\mathrm{T}_{8}$ : Calcium ammonium nitrate $\left(\mathrm{NH}_{4} \mathrm{NO}_{3}\right.$ $\left.\mathrm{CaCO}_{3}\right) @ 0.2 \%$ Foliar Spray

$\mathrm{T}_{9}$ : Calcium ammonium nitrate $\left(\mathrm{NH}_{4} \mathrm{NO}_{3}\right.$ $\left.\mathrm{CaCO}_{3}\right) @ 0.5 \%$ Foliar Spray

$\mathrm{T}_{10}$ : Calcium ammonium nitrate $\left(\mathrm{NH}_{4} \mathrm{NO}_{3}\right.$ $\left.\mathrm{CaCO}_{3}\right) @ 0.8 \%$ Foliar Spray

\section{Results and Discussion}

The data on chemical properties of soil at harvest stage is given in Table 2 and 3.

\section{pH}

Data in Table 2 showed that, different calcium sources and levels significantly influenced on $\mathrm{pH}$ of soil. The highest $\mathrm{pH}$ (7.38) was recorded in the treatment $\mathrm{T}_{9}$ (CAN @ $0.5 \%$ foliar spray) and it was on par withT $_{10}$ (CAN @ $0.8 \%$ foliar spray) with 7.37 and $\mathrm{T}_{4}\left(\mathrm{CaCl}_{2} @ 0.8 \%\right.$ foliar spray $)$ with $7.32 \mathrm{pH}$. Whereas, treatment $\mathrm{T}_{1}$ (water spray) recorded lowest $\mathrm{pH}$ (6.98) in soil after harvest of crop. Which might be due to fall of spray solution on the soil might have increased $\mathrm{pH}$ of soil as compared to control but it was less than initial soil $\mathrm{pH}$. The lower $\mathrm{pH}$ was recorded in control mainly due to water spray.

\section{Electrical conductivity}

The results in Table 2 showed that EC of soil at harvest stage was recorded highest in the treatment received 0.8 per cent of $\mathrm{Ca}$ was applied through $\mathrm{CaCl}_{2}$ as a foliar spray $(0.93$ $\left.\mathrm{dS} \mathrm{m}{ }^{-1}\right)$ followed $\mathrm{T}_{3}\left(\mathrm{CaCl}_{2} @ 0.5 \%\right.$ foliar spray) with $0.91 \mathrm{dS} \mathrm{m}^{-1}$, compared to other treatments. Whereas $T_{1}$ (water spray) showed significantly lower EC value of $0.56 \mathrm{dS}$ $\mathrm{m}^{-1}$. Which might be due to fall of spray solution on the surface of soil increased EC of soil extract as compared to other treatments. But it was more than initial EC of soil extract as the chloride present in $\mathrm{CaCl}_{2}$ act as a salt it helps in increasing EC of soil extract. The lower EC was observed in control.

\section{Organic carbon}

The results in Table 2 clearly showed that, OC of soil at harvest stage varied significantly. The treatment which received 0.5 per cent of $\mathrm{Ca}$ through CAN as a foliar spray (4.9 $\left.\mathrm{g} \mathrm{kg}^{-1}\right)$ recorded significantly lowest OC content followed by $\mathrm{T}_{10}$ (CAN @ $0.8 \%$ foliar spray $)$ and $\mathrm{T}_{7}\left(\mathrm{CaNO}_{3} @ 0.8 \%\right.$ FS) with 5.0 and $5.1 \mathrm{~g} \mathrm{~kg}^{-1}$, respectively compared to other treatments. The control treatment $\mathrm{T}_{1}$ (water spray) recorded highest of OC of $6.9 \mathrm{~g} \mathrm{~kg}^{-1}$.

This might be due to the decomposition of organic matter leads to mineralization of nutrients. Most of the nutrients utilized by plant for its growth and development. Hence OC of soil decreased as compared to control. But it was less than initial. This is because more uptakes of nutrients by plant helps in reduction in OC.

\section{Cation exchange capacity}

There was a significant difference in cation exchange capacity of soil among the treatments (Table 2).

CEC recorded was highest of $22.08 \mathrm{c} \mathrm{mol}\left(\mathrm{p}^{+}\right)$ $\mathrm{kg}^{-1}$ in the treatment $\mathrm{T}_{9}$ (CAN @ $0.5 \%$ foliar spray) and it was closely followed by the $\mathrm{T}_{10}$ (CAN @ $0.8 \%$ foliar spray) with $18.60 \mathrm{c}$ mol $\left(\mathrm{p}^{+}\right) \mathrm{kg}^{-1}$ and $\mathrm{T}_{4}\left(\mathrm{CaCl}_{2} @ 0.8 \%\right.$ foliar spray $)$ with $18.47 \mathrm{c} \mathrm{mol}\left(\mathrm{p}^{+}\right) \mathrm{kg}^{-1}$. The treatment $\mathrm{T}_{1}$ (water spray) recorded lowest of CEC of $15.68 \mathrm{c}$ mol $\left(\mathrm{p}^{+}\right) \mathrm{kg}^{-1}$. The reduction in CEC of soil might be due to reduction in $\mathrm{OC}$ content. 
Available nitrogen, phosphorus, potassium and sulphur

The available $\mathrm{N}$ in soil at harvest stage varied due to various sources and levels of $\mathrm{Ca}$ (Table 2 and 3). Significantly lower status of available NPK (164.34 $\mathrm{kg} \mathrm{ha}^{-1}, 38.49 \mathrm{~kg} \mathrm{ha}^{-1}$, $255.84 \mathrm{~kg} \mathrm{ha}^{-1}$ and $3.72 \mathrm{mg} \mathrm{kg}^{-1}$ ) was recorded in $\mathrm{T}_{9}$ (CAN @ 0.5\% foliar spray) treatment compared to other sources followed by $\mathrm{T}_{10}$ (CAN @ 0.8\% foliar spray) with $(193.32 \mathrm{~kg}$ $\mathrm{ha}^{-1}, 41.13 \mathrm{~kg} \mathrm{ha}^{-1}, 263.06 \mathrm{~kg} \mathrm{ha}^{-1}$ and $3.77 \mathrm{mg}$ $\mathrm{kg}^{-1}$, respectively) and $\mathrm{T}_{4}\left(\mathrm{CaCl}_{2} @ 0.8 \%\right.$ foliar spray) with $203.54 \mathrm{~kg} \mathrm{ha}^{-1}, 42.96 \mathrm{~kg}$ ha 1, $273.39 \mathrm{~kg} \mathrm{ha}^{-1}$ and3.80 mg kg ${ }^{-1}$ were significantly lower compared to other treatments. Treatment $\mathrm{T}_{1}$ (water spray) recorded highest available NPK status of $238.82 \mathrm{~kg} \mathrm{ha}^{-1}, 48.36 \mathrm{~kg} \mathrm{ha}^{-1}, 344.04 \mathrm{~kg} \mathrm{ha}^{-1}$ and $4.38 \mathrm{mg} \mathrm{kg}^{-1}$. This is due to the more uptake of nutrients and utilization by plant for its growth and development. However N, P and $\mathrm{K}$ status found less than initial value. The findings are in accordance with Irget et al., (2011), Ahmad and Mahdi (2012), Lolaei (2012) and Ireneusz (2012),

\section{Exchangeable calcium magnesium}

The exchangeable calcium content of soil varied in all treatments due to the effect of treatments (Table 3). Treatment T9 (CAN @ $0.5 \%$ foliar spray) recorded lowest exchangeable calcium and magnesium status of $5.30 \mathrm{meq} 100 \mathrm{~g}^{-1}$ and $2.57 \mathrm{meq} 100 \mathrm{~g}^{-1}$ followed by $\mathrm{T}_{10}$ (CAN @ $0.8 \%$ foliar spray) with (5.47 meq $100 \mathrm{~g}^{-1}$ and $\left.2.67 \mathrm{meq} 100 \mathrm{~g}^{-1}\right)$ and $\mathrm{T}_{4}\left(\mathrm{CaCl}_{2} @ 0.8 \%\right.$ foliar spray $)$ with 5.53 meq $100 \mathrm{~g}^{-1}$ and 2.77 meq $100 \mathrm{~g}^{-1}$, respectively and were significantly lower compared to other treatments. Treatment $T_{1}$ (water spray) recorded significantly highest amount of exchangeable calcium and magnesium (7.53 meq $100 \mathrm{~g}^{-1}$ and 5.03 meq $\left.100 \mathrm{~g}^{-1}\right)$ in soil. This might be due to the more uptake and utilization of nutrients by for its growth and development.

\section{Available micronutrient status of soil}

Result on the effect of sources and levels of $\mathrm{Ca}$ on available micronutrient status of soil at harvest stages of tomato crop is presented in Table 3. Available micronutrient status in soil at harvest stage varied due to various levels of Ca.

There was a significant difference in the availability of micronutrients in soil among the treatments. Treatment $T_{9}$ (CAN @ $0.5 \%$ foliar spray) recorded lowest available micronutrient status in soil viz., Fe $(10.32 \mathrm{mg}$ $\left.\mathrm{kg}^{-1}\right), \mathrm{Mn}\left(1.96 \mathrm{mg} \mathrm{kg}^{-1}\right), \mathrm{Cu}\left(6.97 \mathrm{mg} \mathrm{kg}^{-1}\right)$ and $\mathrm{Zn}\left(1.94 \mathrm{mg} \mathrm{kg}^{-1}\right)$ followed by $\mathrm{T}_{10}$ (CAN @ $0.8 \%$ foliar spray $)$ and $\mathrm{T}_{4}\left(\mathrm{CaCl}_{2} @ 0.8 \%\right.$ foliar spray) compared to other treatments. However, treatment $T_{1}$ (water spray) recorded significantly higher available micronutrient status viz., $\mathrm{Fe}, \mathrm{Mn}, \mathrm{Cu}$ and $\mathrm{Zn}(23.55,5.77$, $16.65,3.41 \mathrm{mg} \mathrm{kg}^{-1}$, respectively). This might be due to the more uptake and utilization (Yildirim et al., 2009; Lolaei, 2012; Nadeem et al., 2013; Shafeek et al., 2013 in tomato).

\section{Correlation coefficient between plant nutrient status and quality of tomato}

The data on correlation coefficient between plant nutrient status and quality parameters of tomato (Table 4) clearly depicted that, the nutrient content of tomato plant viz., N, P, K and $\mathrm{Ca}$ were found to be positively and significantly correlated with quality parameters viz., ascorbic acid, lycopene, reducing sugar, total soluble solids, fruit firmness, titrable acidity, shelf life, crude protein and physiological loss in weight. The ascorbic acid content $\left(\mathrm{r}=0.913^{* *}\right)$ and TSS $\left(\mathrm{r}=0.864^{* *}\right)$ were found to be highly significantly and positively correlated with $\mathrm{Ca}$ content of plant followed by $\mathrm{P}$ content of plant. The Lycopene $\left(r=0.956^{* *}\right)$ and reducing sugar $\left(\mathrm{r}=0.913^{* *}\right)$ content were highly positively influenced by $\mathrm{S}$ content of plant and PLW $\left(\mathrm{r}=0.902^{* *}\right)$ tomato fruit was highly 
positively influenced by $\mathrm{P}$ content of plant. The titrable acidity $\left(\mathrm{r}=0.940^{* * *}\right)$ and Shelf life $\left(r=0.920^{* *}\right)$ was highly significantly and positively correlated with potassium content of plant (Chauhadry et al., 2012).

Correlation coefficient between Ca content and uptake by plant with growth and yield of tomato

The correlation results in Table 5 indicated that correlation coefficient between $\mathrm{Ca}$ content and uptake were found to be positively and significantly correlated with growth parameters like plant height $\left(\mathrm{r}=0.939^{* *}\right)$, number of branches $\left(\mathrm{r}=0.814^{* *}\right)$, stem diameter $\left(\mathrm{r}=0.911^{* *}\right)$ and yield parameters viz., fruits per plant $\left(\mathrm{r}=0.840^{* * *}\right)$, yield per plant $\left(\mathrm{r}=0.924^{* *}\right)$ and dry matter yield $\left(\mathrm{r}=0.993^{* *}\right)$ followed by $\mathrm{Ca}$ content of tomato plant(Chauhadry et al., 2012).

Table.1 Initial physical and chemical properties of the experimental site

\begin{tabular}{|c|c|}
\hline Physical properties & Value \\
\hline Sand $(\%)$ & 69.23 \\
\hline Silt (\%) & 14.50 \\
\hline Clay $(\%)$ & 16.27 \\
\hline Textural class & Sandy loam \\
\hline Taxonomic class & Typichaplustalf \\
\hline \multicolumn{2}{|l|}{ Chemical properties } \\
\hline pH $(1: 2.5)$ & 7.63 \\
\hline $\begin{array}{l}\text { Electrical conductivity }\left(\mathrm{dS} \mathrm{m}^{-1}\right) \text { at } 25^{0} \mathrm{C}(1: 2 \\
\text { ratio) }\end{array}$ & 0.90 \\
\hline Organic carbon $\left(\mathrm{g} \mathrm{kg}^{-1}\right)$ & 7.10 \\
\hline Cation exchange capacity $\left[\mathrm{cmol}\left(\mathrm{p}^{+}\right) \mathrm{kg}^{-1}\right]$ & 20.50 \\
\hline Available N $\left(\mathrm{kg} \mathrm{ha}^{-1}\right)$ & 301.52 \\
\hline Available $\mathrm{P}_{2} \mathrm{O}_{5}\left(\mathrm{~kg} \mathrm{ha}^{-1}\right)$ & 53.83 \\
\hline Available $\mathrm{K}_{2} \mathrm{O}\left(\mathrm{kg} \mathrm{ha}^{-1}\right)$ & 493.25 \\
\hline Exchangeable Ca $\left(\right.$ meq100g $\left.^{-1}\right)$ & 8.70 \\
\hline Exchangeable Mg $\left(\right.$ meq $\left.^{100 g^{-1}}\right)$ & 6.76 \\
\hline Available S ( $\left.\mathrm{mg} \mathrm{kg}^{-1}\right)$ & 8.20 \\
\hline \multicolumn{2}{|l|}{ DTPA extractable Micronutrients $\left(\mathrm{mg} \mathrm{kg}^{-1}\right)$} \\
\hline Iron & 25.13 \\
\hline Copper & 22.34 \\
\hline Zinc & 4.78 \\
\hline Manganese & 7.11 \\
\hline
\end{tabular}


Table.2 Effect of foliar spray of different sources and levels of calcium on chemical properties of soil at harvest stage

\begin{tabular}{|c|c|c|c|c|c|c|c|}
\hline \multirow[t]{2}{*}{ Treatments } & \multirow[t]{2}{*}{ pH } & \multirow[t]{2}{*}{$\mathrm{EC}\left(\mathrm{dSm}^{-1}\right)$} & \multirow[t]{2}{*}{$\mathrm{OC}\left(\mathrm{gkg}^{-1}\right)$} & \multirow{2}{*}{$\begin{array}{c}\text { CEC } \\
{\left[\mathrm{cmol}\left(\mathrm{p}^{+}\right) \mathrm{kg}^{-1}\right]}\end{array}$} & \multicolumn{3}{|c|}{ Available nutrient $\left(\mathrm{kg} \mathrm{ha}^{-1}\right)$} \\
\hline & & & & & $\mathbf{N}$ & $\mathbf{P}$ & $\mathbf{K}$ \\
\hline $\mathbf{T}_{1}:$ Control (WS) & 6.98 & 0.56 & 6.9 & 20.08 & 238.82 & 48.36 & 344.04 \\
\hline $\mathrm{T}_{2}: \mathrm{CaCl}_{2} @ 0.2 \% \mathrm{FS}$ & 7.00 & 0.78 & 6.7 & 18.60 & 232.13 & 47.34 & 338.99 \\
\hline $\mathrm{T}_{3}: \mathrm{CaCl}_{2} @ 0.5 \% \mathrm{FS}$ & 7.10 & 0.91 & 5.2 & 17.63 & 227.50 & 43.83 & 325.69 \\
\hline $\mathrm{T}_{4}: \mathrm{CaCl}_{2} @ 0.8 \% \mathrm{FS}$ & 7.32 & 0.93 & 5.1 & 16.80 & 203.54 & 42.96 & 273.39 \\
\hline $\mathrm{T}_{5}: \mathrm{CaNO}_{3} @ 0.2 \% \mathrm{FS}$ & 7.01 & 0.60 & 5.8 & 18.47 & 218.27 & 43.22 & 314.14 \\
\hline $\mathrm{T}_{6}: \mathrm{CaNO}_{3} @ 0.5 \% \mathrm{FS}$ & 7.03 & 0.67 & 5.5 & 17.75 & 210.57 & 47.47 & 316.60 \\
\hline $\mathrm{T}_{7}: \mathrm{CaNO}_{3} @ 0.8 \% \mathrm{FS}$ & 7.21 & 0.71 & 5.3 & 16.76 & 218.78 & 48.50 & 332.40 \\
\hline $\mathrm{T}_{8}: \mathrm{CAN} @ 0.2 \% \mathrm{FS}$ & 7.17 & 0.59 & 5.1 & 17.20 & 217.44 & 44.85 & 284.27 \\
\hline $\mathrm{T}_{9}: \mathrm{CAN} @ 0.5 \% \mathrm{FS}$ & 7.38 & 0.63 & 4.9 & 15.68 & 164.34 & 38.49 & 255.84 \\
\hline $\mathrm{T}_{10}: \mathrm{CAN} @ 0.8 \% \mathrm{FS}$ & 7.37 & 0.65 & 5.0 & 15.86 & 193.32 & 41.13 & 263.06 \\
\hline S.Em \pm & 0.03 & 0.02 & 0.04 & 0.37 & 2.86 & 1.14 & 1.42 \\
\hline CD@5\% & 0.09 & 0.07 & 0.11 & 1.10 & 8.44 & 3.36 & 4.18 \\
\hline
\end{tabular}

FS- Foliar spray; WS- Water spray; CAN- Calcium ammonium nitrate

Table.3 Effect of foliar spray of different sources and levels of calcium on secondary and micro nutrient content of soil at harvest stage

\begin{tabular}{|c|c|c|c|c|c|c|c|}
\hline \multirow[t]{2}{*}{ Treatments } & \multicolumn{2}{|c|}{ Exchangeable (meq $100 \mathrm{~g}^{-1}$ ) } & \multicolumn{5}{|c|}{ Available micronutrients (mg kg ${ }^{-1}$ ) } \\
\hline & Ca & Mg & $\begin{array}{c}\text { Available } S \\
\left(\mathrm{mg} \mathrm{kg}^{-1}\right)\end{array}$ & $\mathbf{F e}$ & Mn & $\mathbf{C u}$ & Zn \\
\hline$T_{1}:$ Control (WS) & 7.53 & 5.03 & 4.38 & 23.55 & 5.77 & 16.65 & 3.41 \\
\hline $\mathrm{T}_{2}: \mathrm{CaCl}_{2} @ 0.2 \% \mathrm{FS}$ & 6.30 & 4.83 & 4.03 & 22.09 & 4.50 & 14.36 & 3.21 \\
\hline $\mathrm{T}_{3}: \mathrm{CaCl}_{2} @ 0.5 \% \mathrm{FS}$ & 6.07 & 4.03 & 3.90 & 13.89 & 3.63 & 12.75 & 3.02 \\
\hline $\mathrm{T}_{4}: \mathrm{CaCl}_{2} @ 0.8 \% \mathrm{FS}$ & 5.53 & 2.77 & 3.80 & 13.17 & 3.38 & 7.23 & 2.26 \\
\hline $\mathrm{T}_{5}: \mathrm{CaNO}_{3} @ 0.2 \% \mathrm{FS}$ & 7.10 & 3.93 & 3.98 & 19.72 & 4.28 & 10.11 & 2.78 \\
\hline $\mathrm{T}_{6}: \mathrm{CaNO}_{3} @ 0.5 \% \mathrm{FS}$ & 6.70 & 3.00 & 3.96 & 16.32 & 4.06 & 9.40 & 2.57 \\
\hline $\mathrm{T}_{7}: \mathrm{CaNO}_{3} @ 0.8 \% \mathrm{FS}$ & 5.97 & 2.87 & 3.84 & 16.20 & 3.72 & 8.51 & 2.53 \\
\hline $\mathrm{T}_{8}: \mathrm{CAN} 0.2 \% \mathrm{FS}$ & 6.77 & 3.27 & 3.82 & 13.18 & 3.79 & 8.80 & 2.41 \\
\hline T9: CAN@ $0.5 \%$ FS & 5.30 & 2.57 & 3.72 & 10.32 & 1.96 & 6.97 & 1.94 \\
\hline $\mathrm{T}_{10}: \mathrm{CAN} @ 0.8 \% \mathrm{FS}$ & 5.47 & 2.67 & 3.77 & 11.68 & 2.58 & 7.19 & 2.23 \\
\hline S.Em \pm & 0.09 & 0.06 & 0.07 & 0.09 & 0.07 & 0.13 & 0.02 \\
\hline CD@ $5 \%$ & 0.27 & 0.17 & 0.22 & 0.28 & 0.21 & 0.39 & 0.07 \\
\hline
\end{tabular}

FS- Foliar spray; WS- Water spray; CAN- Calcium ammonium nitrate 
Table.4 Correlation coefficient (r) between nutrient status of plant with quality parameters of tomato

\begin{tabular}{|c|c|c|c|c|c|c|c|c|c|}
\hline & $\begin{array}{c}\text { Ascorbic } \\
\text { acid }\end{array}$ & Lycopene & $\begin{array}{c}\text { Reducing } \\
\text { sugar }\end{array}$ & TSS & $\begin{array}{l}\text { Fruit. } \\
\text { firmness }\end{array}$ & $\begin{array}{l}\text { Titrable } \\
\text { acidity }\end{array}$ & Shelf life & $\begin{array}{c}\text { Crude } \\
\text { protein }\end{array}$ & PLW \\
\hline Nitrogen & $0.839^{* *}$ & $0.902^{* *}$ & $0.780^{* *}$ & $0.680^{*}$ & $0.726^{*}$ & $0.881^{* *}$ & $0.831^{* *}$ & $0.807^{* *}$ & $0.903^{* *}$ \\
\hline Phosphorus & $0.875^{* *}$ & $0.956^{* *}$ & $0.910^{* *}$ & $0.776^{* *}$ & $0.814^{* *}$ & $0.912^{* *}$ & $0.892^{* *}$ & $0.840^{* *}$ & $0.951^{* *}$ \\
\hline potassium & $0.830^{* *}$ & $0.955^{\text {** }}$ & $0.862^{* *}$ & $0.704^{*}$ & $0.781^{* *}$ & $0.940^{* *}$ & $0.920^{* *}$ & $0.803^{* *}$ & $0.945^{\text {** }}$ \\
\hline Calcium & $0.913^{* *}$ & $0.865^{\text {** }}$ & $0.912^{* *}$ & $0.864^{* *}$ & $0.857^{* *}$ & $0.810^{* *}$ & $0.704^{*}$ & $0.856^{* *}$ & $0.902^{* *}$ \\
\hline Magnesium & $0.849^{* *}$ & $0.817^{* *}$ & $0.906^{* *}$ & $0.718^{* *}$ & $0.768^{* *}$ & $0.808^{* *}$ & $0.680^{*}$ & $0.895^{* *}$ & $0.909^{* *}$ \\
\hline Sulphur & $0.894^{* *}$ & $0.978^{* *}$ & $0.913^{* *}$ & $0.781^{* *}$ & $0.806^{* *}$ & $0.914^{* *}$ & $0.885^{* *}$ & $0.865^{* *}$ & $0.872^{* * *}$ \\
\hline
\end{tabular}

**. Correlation is significant at the 0.01 level

*. Correlation is significant at the 0.05 level

PLW: Physiological loss in weight

Table.5 Correlation coefficient ( $\mathrm{r}$ ) between Ca content and uptake by plant with growth and yield of tomato

\begin{tabular}{|l|c|c|c|c|c|c|c|}
\hline & Plant height & $\begin{array}{c}\text { No of } \\
\text { branches }\end{array}$ & $\begin{array}{c}\text { Stem } \\
\text { diameter }\end{array}$ & Fruits plant & Yield plant & & Dry matter yield \\
& & & & & \\
\hline Ca content & $0.920^{* *}$ & $0.756^{*}$ & $0.845^{* *}$ & $0.822^{* *}$ & $0.893^{* *}$ & $0.892^{* *}$ \\
\hline Ca uptake & $0.939^{* *}$ & $0.814^{* *}$ & $0.911^{* *}$ & $0.840^{* *}$ & $0.924^{* *}$ & $0.923^{* *}$ & $0.950^{* *}$ \\
\hline
\end{tabular}

**. Correlation is significant at the 0.01 level

*. Correlation is significant at the 0.05 level

Table.6 Correlation coefficient (r) between Ca content and uptake by plant with quality of tomato

\begin{tabular}{|l|c|c|c|c|c|c|c|c|c|c|}
\hline & $\begin{array}{c}\text { Ascorbic } \\
\text { acid }\end{array}$ & Lycopene & $\begin{array}{c}\text { Reducing } \\
\text { sugar }\end{array}$ & TSS & $\begin{array}{c}\text { Fruit } \\
\text { firmness }\end{array}$ & $\begin{array}{c}\text { Titrable } \\
\text { acidity }\end{array}$ & $\begin{array}{c}\text { Shelf } \\
\text { life }\end{array}$ & $\begin{array}{c}\text { Crude } \\
\text { protein }\end{array}$ & $\begin{array}{c}\text { Pericarp } \\
\text { thickness }\end{array}$ & $\begin{array}{c}\text { PLW } \\
\text { Ca content }\end{array}$ \\
\hline $0.913^{* *}$ & $0.865^{* *}$ & $0.930^{* *}$ & $0.864^{* *}$ & $0.857^{* *}$ & $0.810^{* *}$ & $0.704^{*}$ & $0.854^{* *}$ & $-0.902^{* *}$ & $0.933^{* *}$ \\
\hline Ca uptake & $0.812^{* *}$ & $0.920^{* *}$ & $0.943^{* *}$ & $0.793^{* *}$ & $0.813^{* *}$ & $0.898^{* *}$ & $0.877^{* *}$ & $0.778^{* *}$ & $-0.927^{* *}$ & $0.923^{* *}$ \\
\hline
\end{tabular}

**. Correlation is significant at the 0.01 level

*. Correlation is significant at the 0.05 level

PLW: Physiological loss in weight; TSS: Total soluble solids 


\section{Correlation coefficient between Ca content} and uptake by plant with quality of tomato

The data on relationship between Ca content and uptake with tomato fruit quality (Table 6) clearly depicted that, correlation coefficient between $\mathrm{Ca}$ content and uptake with quality of tomato showed a positive and significant correlation with quality parameters viz., ascorbic acid, lycopene, reducing sugar, total soluble solids, fruit firmness, titrable acidity, shelf life, crude protein and physiological loss in weight and negatively and significantly correlated with pericarp thickness.

Ca content in tomato plant was found to be positively and significantly correlated with quality parameters viz., ascorbic acid $\left(\mathrm{r}=0.913^{* *}\right)$, TSS $\left(\mathrm{r}=0.864^{* *}\right)$, fruit firmness $\left(\mathrm{r}=0.857^{* *}\right)$, crude protein $\left(\mathrm{r}=0.854^{* *}\right)$ and PLW ( $\mathrm{r}=0.933^{* * *}$ ) followed by Ca uptake by tomato plant. The lycopene $\left(\mathrm{r}=0.920^{* *}\right)$, reducing sugar $\left(\mathrm{r}=0.943^{* * *}\right)$, titrable acidity $\left(\mathrm{r}=0.898^{* *}\right)$, shelf life $\left(\mathrm{r}=0.877^{* *}\right)$ were highly and positively influenced by $\mathrm{Ca}$ uptake by tomato plant and negatively correlation with pericarp thickness $\left(\mathrm{r}=-0.927^{* * *}\right)$. The findings are in accordance with Chauhadry et al., (2012) indicated a positive correlation between plant growth and application of calcium chloride in tomato.

\section{Conclusion}

It can be concluded from the experimental results that, $\mathrm{Ca}$ found to be effective and significantly increased fruit quality. It was positively and significantly correlated with growth, yield and most likely fruit quality parameters viz., Ascorbic acid, Lycopene, Reducing sugar, TSS, Fruit firmness, Titrable acidity, Shelf life, Crude protein, Pericarp thickness and PLW. However, the highest effect and use efficiency was observed due to foliar spray of CAN (calcium ammonium nitrate) fertilizer with a concentration of 0.5
$\%$ followed by foliar spray of $\mathrm{CaCl}_{2}$ at $0.8 \%$ compare to other sources and concentrations.

\section{References}

Ahmad, A. and Mahdi, B., 2012, Foliar application of calcium borate and micronutrients effects on some characters of apple fruits in Shirvan region. Annals Biolo. Res., 3(1): 527533.

Black, C. A., 1965, Methods of Soil Analysis, Part II, Chemical and microbiological properties, No. 9 series, Agronomy, Am. Soc. Agron. Madison, Wisconsin, USA.

Chauhadry, M. A., Muhammad, A. P., Muhammad, A.P., Muhammad, I. A., Muhammad, W.H., Shabbir, H. and Nasir, M., 2012, Assessment of various growth and yield attributes of tomato in response to pre-harvest applications of calcium chloride, Pakistan. J. Life Soc. Sci., 10(2): 102105.

Gomez, K. A. and Gomez, A. A., 1984, Statistical procedures for agricultural research (2 ed.). John Wiley and sons, New York, 680p.

Ireneusz, O., 2012, The Impact of foliar application of calcium fertilizers on the quality of high bush blueberry fruits belonging to the 'duke' cultivar. Ochmian Not Bot. Horti. Agrobo, 40(2): 163-169.

Irget, M. E., Aydin, M., Oktay, M., Tutam, Aksoy, U. and Nalbant, M. M., 2011, Effects of foliar potassium nitrate and calcium nitrate application on nutrient content and fruit quality of fig. Pakistan J. Life Soci. Sci., 11(7): 2028.

Jackson, M. L., 1973, Soil Chemical Analysis. Prentice Hall Pvt. Ltd., New Delhi.

Lindsay, W.L. and Norvell, W.A., 1978, Development of a DTPA soil test for 
Zn, Fe, Mn and Cu. Soil Sci. Soc. Am. Proc., 42: 421-428.

Lolaei, A., 2012, Effect of calcium chloride on growth and yield of tomato under sodium chloride stress. J. Ornamental Horti. Plants, 2(3): 155-160.

Nadeem, A., Abbasi, Lubna, Z., Hammad, A. and Abdul, A. Q., 2013, Effects of naphthalene acetic acid and calcium chloride application on nutrient uptake, growth, yield and post-harvest performance of tomato fruit. Pakistan J. Bot., 45(5): 1581-1587.

Shafeek, M. R., Helmy, Y. I., Tohamy, W. A. and Abagy, H. M., 2013, Changes in growth, yield and fruit quality of cucumber (Cucumis sativus L.) in response to foliar application of calcium and potassium nitrate under plastic house conditions. Res. J. Agric. Biolog. Sci., 9(3): 114-118.

Subbaiah, B. V. and Asija, G. L., 1956, A rapid procedure for determination of available nitrogen in soil. Curr. Sci., 25: 259 - 260.

Yildirim, E., Karlidag, H. and Turan, M., 2009, Mitigation of salt stress in strawberry by foliar $\mathrm{K}, \mathrm{Ca}$ and $\mathrm{Mg}$ nutrient supply.Pl. Soil Environ., 5(5): 213-221.

\section{How to cite this article:}

Tejashvini, A., and Thippeshappa, G.N. 2019. Effect of Foliar Application of Different Sources and Levels of Calcium on Physico-Chemical Properties of Harvested Soil and Correlation of Calcium Nutrition with Fruit Quality. Int.J.Curr.Microbiol.App.Sci. 8(02): 1447-1455. doi: https://doi.org/10.20546/ijcmas.2019.802.168 